\title{
RELATIONSHIPS BETWEEN THE PHYSICO-CHEMICAL WATER PARAMETERS AND ZOOPLANKTON FAUNA OF TIGA LAKE, KANO, NIGERIA
}

Akindele, E.O.

Department of Zoology, Obafemi Awolowo University, Ile_Ife, Nigeria; current address: Department of Biological Sciences, Bowen University, P.M.B. 284, Iwo, Nigeria.

eoakindele@yahoo.com

\section{ABSTRACT}

This study investigated the relationships between zooplankton fauna and physico-chemical water parameters of Tiga Lake, Kano, Nigeria from March 2009 to March 2011. Water transparency, pH, $\mathrm{Cr}, \mathrm{SO}_{4}{ }^{2-}$ and dissolved oxygen (DO) showed significant positive correlations $(\mathrm{p}<0.05)$ with species occurrence, while total solids (TS), total suspended solids (TSS), turbidity, $\mathrm{NO}_{3}^{-} \mathrm{and} \mathrm{PO}_{4}{ }^{3-}$ showed significant negative correlations $(p<0.05)$ with species occurrence. There were significant positive correlations $(p<0.05)$ between zooplankton abundance and conductivity, total alkalinity, total dissolved solids (TDS), $\mathrm{Ca}^{2+}, \mathrm{Na}^{+}$and $\mathrm{K}^{+}$. The general chemical characteristics ( $\mathrm{pH}$, total alkalinity, conductivity and TDS) and major ions ( $\mathrm{Ca}^{2+}, \mathrm{Na}^{+}$and $\left.\mathrm{K}^{+}\right)$were all within the permissible limits for aquatic life, and they showed direct relationships with the zooplankton fauna of the lake. Physical parameters (water transparency, turbidity, TS and TSS) and nutrient content ( $\mathrm{NO}_{3}^{-}$and $\mathrm{PO}_{4}{ }^{3-}$ ) were considered to be limiting on the occurrence and distribution of zooplankton in Tiga Lake. The ecological relationship between zooplankton and physico-chemical parameters of the lake is an indication of its suitability for aquatic life.

Keywords; Tiga Lake; relationship; water parameters; zooplankton fauna

\section{INTRODUCTION}

Plankton are normally found in different types of aquatic environments and their occurrence and distribution are influenced by ambient physical factors such as wind, temperature, salinity, dissolved oxygen etc (Pilkaityte and Razinkivas, 2006). Chemical factors such as high saline levels can be stressful for all organisms, including plankton because of the coupled effects of osmotic stress and ionic stress resulting from high concentrations of ions (Marcarelli et al., 2006). The metabolic rate of aquatic organisms is related to temperature and in warm waters, respiration rates increase leading to increased oxygen consumption and increased decomposition of organic matter (Chapman and Kimstach, 2006). Fish, insects, zooplankton, phytoplankton and other aquatic organisms all have optimum temperature ranges. As temperature gets too far above or below this optimum range, the number of individual species decreases until finally there are few or none (Moore, 1989; Michaud, 1991). The $\mathrm{pH}$ of an aquatic ecosystem is also important because it is closely linked to biological productivity (Carr and Neary, 2006). Most surface waters have a pH between 6.0 and 8.5 , and values below 6.0 can be hazardous to aquatic life (Mohan and Kumar, 1998) while the optimum value is between 7.5 and 8.5 (Boyd, 1979).

Zooplankton constitute an important link in the aquatic food web through the transfer of chemical energy from the autotrophic phytoplankton to higher trophic organisms such as macroinvertebrates and fish. Their distribution, occurrence and abundance can also be used to assess the productivity of an aquatic ecosystem. Being part of the biotic community, their occurrence and abundance is closely linked to the physico-chemical water condition of the system in which they are found. This study was motivated by the need to establish an ecological relationship between the physico-chemical water condition and the biotic component of Tiga Lake, using its zooplankton fauna as an index. The physico-chemical water parameters studied included: water temperature, water transparency, turbidity, dissolved oxygen, biochemical oxygen demand $\left(\mathrm{BOD}_{5}\right)$, nitrate, phosphate, $\mathrm{pH}$, conductivity, total dissolved solids (TDS), total suspended solids (TSS), total solids (TS) and total alkalinity. Others were $\mathrm{Ca}^{2+}, \mathrm{Mg}^{2+}, \mathrm{Na}^{+}, \mathrm{K}^{+}$, $\mathrm{Cl}^{-}$and $\mathrm{SO}_{4}{ }^{2-}$.

\section{MATERIALS AND METHODS \\ The Study Area}

The study area was Tiga Lake, Nigeria's second largest artificial lake (based on volume) which is located some $70 \mathrm{~km}$ south of the ancient city of Kano. It is impounded by a large dam with a height of $48 \mathrm{~m}$, crest length of $6 \mathrm{~km}$ and $1,974 \times 10^{6} \mathrm{Km}^{3}$ reservoir capacity (HASKONING, 1978). The Lake lies between longitudes $008^{\circ} 18^{\prime} \mathrm{E}$ and $008^{\circ} 35^{\prime} \mathrm{E}$, and latitudes $11^{\circ} 18^{\prime} \mathrm{N}$ and $11^{\circ} 27^{\prime} \mathrm{N}$. It is located some $70 \mathrm{~km}$ south of the metropolitan city of Kano.

Five sampling stations (A, B, C, D \& E) were established on the Lake covering both the riverine and the lacustrine sections (Figure 1). Station A was established close to Babuha Village, at the River Kano axis of the lake. Station B was in the lacustrine section of the lake, downstream of Station A and adjacent to Bature house, Rurum village. Station $C$ was also in the lacustrine section, downstream of both Stations B and E, but upstream of Station D (dam site). Station E was established at River Duku axis of the lake close to Yaryasa village. 


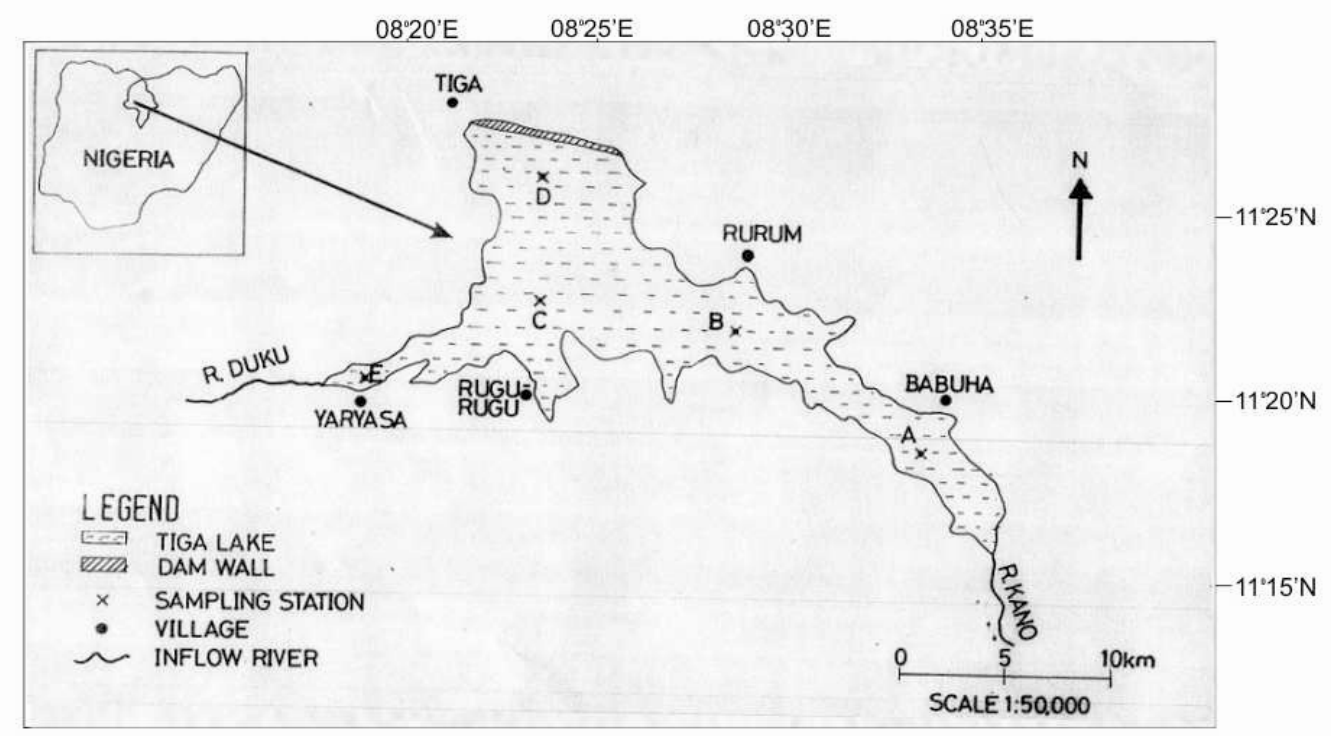

Figure 1: Tiga Lake showing the sampling stations

\section{Sample Collection and Field Determinations}

Water samples were collected on monthly basis from March 2009 to March 2011 from the limnetic zone of the lake. Water samples for physico-chemical analyses were collected in sterile plastic containers which had been rinsed with distilled water and water from the site. Water temperature, water transparency and $\mathrm{pH}$ were determined in-situ by using mercury-in-glass thermometer, calibrated Secchi disc and calibrated field $\mathrm{pH}$ meter ( $\mathrm{pH}$ Testr2) respectively. Samples for dissolved oxygen analysis were also fixed in-situ with Winkler's reagents $\mathrm{A}\left(\mathrm{MnSO}_{4}\right)$ and $\mathrm{B}$ (alkali iodide). $\mathrm{BOD}_{5}$ samples were collected in dark bottles $(250 \mathrm{ml})$ and kept inside a dark cupboard in the laboratory over a five-day period. Zooplankton samples were collected by filtering 20 litres of water through plankton net of $60 \mu \mathrm{m}$ mesh size and reducing them to concentrate volume of $30 \mathrm{ml}$ which were later preserved in $5 \%$ formalin.

\section{Laboratory Analyses}

Turbidity was determined by nephelometric method using a turbidity meter at $540 \mathrm{~nm}$ (APHA et al. 1995). TS, TSS and TDS were determined by gravimetric method (APHA et al., 1995), while DO and $\mathrm{BOD}_{5}$ were determined by iodometic titration (Goltermann et al, 1978). Total alkalinity was determined by acid-base titration method while chloride ion was determined by Mohr titration method. Complexiometric titration method was employed in determining both calcium and magnesium ions (Goltermann et al., 1978). $\mathrm{SO}_{4}{ }^{2-}$ was determined by turbidimetric method while $\mathrm{NO}_{3}{ }^{-}$ and $\mathrm{PO}_{4}^{3-}$ were determined spectrophotometrically. Flame emission spectrophotometer was used for determining $\mathrm{Na}^{+}$and $\mathrm{K}^{+}$(Goltermann et al., 1978).

Zooplankton samples were examined under a calibrated Olympus 504161 compound light microscope microscope fitted with an ocular micrometer. Observed zooplankters were drawn to scale and their photomicrographs were also taken. Standard identification guides (Egborge and Chigbu, 1988; Akinbuwa, 1999; Egborge, 1994; Fernando, 2002) were used in identifying the observed zooplankton. The abundance of zooplankton was determined from the count records of the final concentrate volume in relation to their original volume of water strained through the plankton net, using the formula given below

$\begin{array}{cc}\text { Where, } A= & \text { organism } / \mathrm{m}^{3} \text { of original water } \\ \text { We } & \text { Number of a particular species in } \\ \text { the counting chamber } & \\ b= & \text { Original volume of water (20 litres) } \\ c= & \text { Total concentrate volume of water } \\ \text { viewed }(4.5 \mathrm{ml}) & \\ d= & \text { Final concentrate volume }(5 \mathrm{ml})\end{array}$

\section{Statistical Analyses}

Descriptive statistics as well as regression and correlation analysis were employed in relating the physico-chemical parameters with zooplankton occurrence and abundance. 


\section{RESULTS}

\section{Zooplankton fauna}

Observed zooplankton groups in this study were protozoans, rotifers, cladocerans, copepods, ostracods and insects. A total of 28, 35, 37, 40 and 32 species were recorded in Stations A, B, C, D and E respectively with abundance values of 31,482 organisms $/ \mathrm{m}^{3}, \quad 36,252$ organisms $/ \mathrm{m}^{3}, \quad 38,160$ organisms $/ \mathrm{m}^{3}, 77,220$ organisms $/ \mathrm{m}^{3}$ and 181,390 organisms $/ \mathrm{m}^{3}$. The classification and composition of the observed zooplankton is given in Table 1.

Table 1: Classification and composition of zooplankton in Tiga Lake, Kano, Nigeria (March 2009March 2011)

\begin{tabular}{|c|c|c|c|c|}
\hline Phylum & Class & Order & Family & Genus/Species \\
\hline \multirow[t]{2}{*}{ Protozoa } & Sarcodina & Amoebida & Amoebidae & Amoeba radiata \\
\hline & Tubulinea & Arcellinida & Arcellinidae & Arcella sp. \\
\hline \multirow[t]{25}{*}{ Rotifera } & Eurotatoria & Ploima & Asplanchnidae & $\begin{array}{l}\text { Asplanchna brightwelli } \\
\text { A. priodonta }\end{array}$ \\
\hline & & & Brachionidae & Anuraeopsis racenensis \\
\hline & & & & Brachionus angularis \\
\hline & & & & Brachionus bennini \\
\hline & & & & Brachionus calyciflorus \\
\hline & & & & Brachionus falcatus \\
\hline & & & & Brachionus plicatilis \\
\hline & & & & Brachionus quadridentatus \\
\hline & & & & Keratella cochlearis cochlearis \\
\hline & & & & Keratella lenzi \\
\hline & & & & Keratella tropica \\
\hline & & & & Notholca sp. \\
\hline & & & Colurellidae & Lepadella patella \\
\hline & & & & Lepadella ovalis \\
\hline & & & Dicranophoridae & Dicranophorus sp. \\
\hline & & & & Encentrum felis \\
\hline & & & Euchlanidae & Euchlanis dilatata \\
\hline & & & Gastropodidae & Ascomorpha sp. \\
\hline & & & Lecanidae & Lecane leontina \\
\hline & & & Synchaetidae & Polyarthra sp. \\
\hline & & & Trichocercidae & Trichocerca cylindrica \\
\hline & & & Trichotriidae & Macrochaetus collinsi \\
\hline & & Flosculariacea & Filinidae & Filinia opoliensis \\
\hline & & & & Filinia terminalis \\
\hline & & & Testudinellidae & Testudinella patina \\
\hline \multirow[t]{25}{*}{ Arthropoda } & Copepoda & Cyclopoida & Cyclopidae & Halicyclops korodiensis \\
\hline & & & & Halicyclops troglodytes \\
\hline & & & & Eucyclops macrurus \\
\hline & & & & Microcyclops varicans \\
\hline & & & & Thermocyclops crassus \\
\hline & & & & Thermocyclops neglectus \\
\hline & & Calanoida & Calanoidae & Thermodiaptamus yabensis \\
\hline & Brachiopoda & Cladocera & Bosminidae & Bosmina longirostris \\
\hline & & & Chydoridae & Camptocercus rectirostris \\
\hline & & & & Alona holdeni \\
\hline & & & & Alona karua \\
\hline & & & & Alona pulchella \\
\hline & & & & Alona rectangula \\
\hline & & & Daphnidae & Scapholeberis kingi \\
\hline & & & Macrothricidae & Macrothrix laticornis \\
\hline & & & Moiniidae & Moina micrura \\
\hline & & & & Moinodaphnia macleayi \\
\hline & & & Sididae & Diaphanosoma excisum \\
\hline & Ostracoda & Podocopida & Candonidae & Physocypria crenulata \\
\hline & & & Cyprididae & Chrissia humilis \\
\hline & & & & Hemicypris ovata \\
\hline & & & Enthocytheridae & Entocythere columbia \\
\hline & Insecta & Diptera & Ceratopogonidae & Ceratopogonid sp. \\
\hline & & & Chaoboridae & Chaoborus sp. \\
\hline & & & Chironomidae & Chironomid sp. \\
\hline
\end{tabular}




\section{Zooplankton Fauna in Relation to Physico- chemical Water Parameters}

The mean values of the investigated physico-chemical water parameters in the five stations are given in Table 2. The relationship between each physico-chemical water parameter and zooplankton species occurrence/abundance is provided in Table 3. Water transparency, $\mathrm{pH}$, sulphate, $\mathrm{Cl}^{-}$and dissolved oxygen showed significant positive correlation with species occurrence. Nitrate, phosphate and three hydro-physical parameters (TS, TSS and turbidity) showed significant inverse correlations with species occurrence. Water transparency and $\mathrm{pH}$ showed significant correlation $(p \leq 0.05)$, while TS, TSS, turbidity, $\mathrm{Cl}^{-}$and $\mathrm{PO}_{4}^{3-}$ showed

Table 2: Mean Values of Physico-chemical Water Parameters in Five Selected Stations of Tiga Lake (March 2009-March 2011)

\begin{tabular}{|c|c|c|c|c|c|c|}
\hline \multirow[t]{2}{*}{ Water Parameter } & \multicolumn{5}{|c|}{ Sampling Station } & \multirow[b]{2}{*}{ RSSF } \\
\hline & $\mathbf{A}$ & B & C & D & $\mathbf{E}$ & \\
\hline Water Temp. $\left({ }^{\circ} \mathrm{C}\right)$ & 25.3 & 26.7 & 27.7 & 27.9 & 28.0 & - \\
\hline Water Transparency (m) & 0.26 & 0.41 & 0.53 & 0.58 & 0.14 & $<30.0^{\circ} \mathrm{C}^{*}$ \\
\hline Turbidity (NTU) & 107.9 & 39.1 & 21.2 & 18.6 & 50.8 & $<25$ NTU $^{* *}$ \\
\hline $\mathrm{TS}(\mathrm{mg} / \mathrm{L})$ & 312 & 126 & 115 & 104 & 273 & - \\
\hline TSS (mg/L) & 258 & 84 & 73 & 63 & 157 & - \\
\hline TDS (mg/L) & 54 & 42 & 42 & 41 & 116 & - \\
\hline $\mathrm{pH}$ & 7.07 & 7.28 & 7.31 & 7.41 & 7.34 & $6.0-8.5^{*}$ \\
\hline Conductivity ( $\mu S / \mathrm{cm})$ & 94.4 & 74.2 & 73.7 & 73.0 & 209.9 & $<1000 \mu / \mathrm{Scm}^{*}$ \\
\hline Total Alkalinity $\left(\mathrm{mgCaCO}_{3} / \mathrm{L}\right)$ & 34 & 24 & 25 & 26 & 78 & $10-120 \mathrm{mg} / \mathrm{L}^{* *}$ \\
\hline $\mathrm{Ca}^{2+}(\mathrm{mg} / \mathrm{L})$ & 8.17 & 6.25 & 6.44 & 6.32 & 13.34 & $<15 \mathrm{mg} / \mathrm{L}^{*}$ \\
\hline $\mathrm{Mg}^{2+}(\mathrm{mg} / \mathrm{L})$ & 2.34 & 1.17 & 1.13 & 1.35 & 0.87 & $1-100 \mathrm{mg} / \mathrm{L}^{*}$ \\
\hline $\mathrm{Na}^{+}(\mathrm{mg} / \mathrm{L})$ & 6.24 & 4.06 & 3.99 & 3.91 & 7.07 & $<50 \mathrm{mg} / \mathrm{L}^{*}$ \\
\hline $\mathrm{K}^{+}(\mathrm{mg} / \mathrm{L})$ & 3.02 & 2.51 & 2.57 & 2.52 & 9.09 & $<10 \mathrm{mg} / \mathrm{L}^{*}$ \\
\hline $\mathrm{Cl}^{-}(\mathrm{mg} / \mathrm{L})$ & 7.43 & 4.54 & 4.45 & 4.40 & 11.7 & $<10 \mathrm{mg} / \mathrm{L}^{*}$ \\
\hline $\mathrm{SO}_{4}^{2-}(\mathrm{mg} / \mathrm{L})$ & 3.66 & 4.83 & 5.11 & 5.75 & 4.05 & $2-80 \mathrm{mg} / \mathrm{L}^{*}$ \\
\hline $\mathrm{DO}(\mathrm{mg} / \mathrm{L})$ & 5.8 & 7.4 & 7.6 & 7.9 & 6.2 & $5.0-9.0 \mathrm{mg} / \mathrm{L}^{*}$ \\
\hline $\mathrm{BOD}_{5}(\mathrm{mg} / \mathrm{L})$ & 2.4 & 2.2 & 2.4 & 2.4 & 3.3 & $3.0-6.0 \mathrm{mg} / \mathrm{L}^{*}$ \\
\hline $\mathrm{PO}_{4}^{3-}(\mathrm{mg} / \mathrm{L})$ & 0.29 & 0.18 & 0.18 & 0.18 & 0.21 & $0.1 \mathrm{mg} / \mathrm{L}^{* *}$ \\
\hline $\mathrm{NO}_{3}{ }^{-}(\mathrm{mg} / \mathrm{L})$ & 1.33 & 0.61 & 0.51 & 0.39 & 0.77 & $5 \mathrm{mg} / \mathrm{L} \mathrm{NO}_{3}{ }^{-} \mathrm{N}^{*}$ \\
\hline
\end{tabular}

Source: * Chapman and Kimstach, 2006; ** Moore, 1989 and Michaud, 1991

Key: RSSF = Recommended Standard for Surface Freshwaters

Table 3: Relationship between Physico-chemical Parameters and Zooplankton Fauna of Tiga Lake (March 2009-March 2011)

\begin{tabular}{|c|c|c|c|c|}
\hline 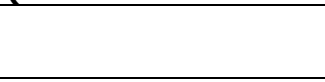 & $\begin{array}{l}\text { Species } \\
\text { occurrence }\end{array}$ & & $\begin{array}{l}\text { Zooplankton } \\
\text { abundance }\end{array}$ & \\
\hline Parameter $(n=5)$ & Cc (r) & Regression equation & Cc (r) & Regression equation \\
\hline Water temp. $\left({ }^{\circ} \mathrm{C}\right)$ & 0.7149 & $Y=1.2489-73.859 x$ & 0.5894 & $Y=58.875-1519.3 x$ \\
\hline Water transp. (m) & $0.8433^{*}$ & $Y=24.845+24.852 x$ & -0.5917 & $Y=217.35 x-366.25$ \\
\hline $\mathrm{TS}(\mathrm{mg} / \mathrm{L})$ & $-0.9320 * *$ & $Y=43.138 x-0.0470$ & 0.3562 & $Y=0.6925-52.207 x$ \\
\hline TSS (mg/L) & $-0.9482 * *$ & $Y=41.518 x-0.0562$ & 0.0617 & $Y=0.8290-28.324 x$ \\
\hline Turbidity (NTU) & $-0.9411^{* *}$ & $Y=40.454 x-0.1274$ & -0.1006 & $Y=165.85 x-1.878$ \\
\hline $\mathrm{pH}$ & 0.8479* & $Y=35.541-224.37 x$ & 0.4405 & $Y=523.92-3738.2 x$ \\
\hline Conductivity ( $\mu \mathrm{S} / \mathrm{cm})$ & -0.4225 & $Y=42.587 x-0.0779$ & $0.9337 * *$ & $Y=1.1481-44.083 x$ \\
\hline $\begin{array}{l}\text { Total alkalinity } \\
\left(\mathrm{mgCaCO}_{3} / \mathrm{L}\right)\end{array}$ & -0.4322 & $Y=41.822 x-0.1982$ & $0.9321 * *$ & $Y=2.9225-32.813 x$ \\
\hline TDS (mg/L) & -0.4283 & $Y=42.942 x-0.1437$ & $0.9321 * *$ & $Y=2.1183-49.325 x$ \\
\hline Calcium (mg/L) & -0.5144 & $Y=46.801 x-1.5251$ & $0.8960 * *$ & $Y=22.482-106.22 x$ \\
\hline Magnesium (mg/L) & -0.5598 & $Y=45.582 x-8.1483$ & -0.5444 & $Y=241.43 x-120.12$ \\
\hline Sodium (mg/L) & -0.6623 & $Y=45.911 x-2.1243$ & $0.8020 *$ & $Y=31.316-93.096 x$ \\
\hline Potassium (mg/L) & -0.3539 & $Y=40.686 x-1.2286$ & $0.9531 * * *$ & $Y=18.111-16.068 x$ \\
\hline Chloride (mg/L) & $0.9152 * *$ & $Y=53.189 x-3.5674$ & -0.0239 & $Y=353.58 x-52.589$ \\
\hline Sulphate (mg/L) & $0.9886 * * *$ & $Y=5.5284+8.5347 x$ & -0.2178 & $Y=457.9 x-81.497$ \\
\hline $\mathrm{DO}(\mathrm{mg} / \mathrm{L})$ & $0.9591 * * *$ & $Y=4.93+0.0671 x$ & -0.3207 & $Y=582.72 x-72.676$ \\
\hline $\mathrm{BOD}_{5}(\mathrm{mg} / \mathrm{L})$ & -0.2948 & $Y=62.179 x-10.952$ & 0.2268 & $Y=293.49-642.46 x$ \\
\hline Nitrate (mg/L) & $-0.9560 * * *$ & $Y=43.382 x-12.375$ & -0.0990 & $Y=209 x-182.43$ \\
\hline Phosphate (mg/L) & $-0.9328 * *$ & $Y=67.326 x-166.61$ & 0.0282 & $Y=2456.1 x-408.78$ \\
\hline
\end{tabular}

*Significant, $\mathrm{p} \leq 0.05, \mathrm{r}=0.7545, * *$ Highly significant, $\mathrm{p} \leq 0.01, \mathrm{r}=0.8745, * * *$ Very highly significant, $\mathrm{p} \leq 0.001$, $\mathrm{r}=0.9507, \mathrm{Cc}=$ Correlation coefficient 


\section{DISCUSSION}

Hydro-physical parameters (water transparency, TS, TSS and turbidity) played a major role in the occurrence of zooplankton species in Tiga Lake during the study period. Water transparency was found to have a direct relationship with zooplankton species occurrence in the lake. High water transparency increases the euphotic zone in an aquatic ecosystem which in turn favours phytoplankton growth and primary productivity. Any factor that enhances the production of phytoplankton is most likely going to enhance the production of zooplankton also, since the latter are nutritionally dependent on the former. Transparency however showed an indirect relationship ( $p>0.05$ ) with abundance of zooplankton, an account similarly given in the Imo River estuary (Atoma, 2004) and in Onah Lake, Nigeria (Olele and Ekelemu, 2008). Biological productivity in tropical lakes is mainly limited by the introduction of highly turbid waters and wind-induced turbulence during the wet season (Carr and Neary, 2006). This may be the reason for the inverse relationships that existed between turbidity, TS, TSS and zooplankton species occurrence. Turbidity and TSS are inter-related and they are both capable of extinguishing incident solar radiation in a lake, thereby affecting the phytoplankton primary production and by extension, the zooplankton secondary production. The mean values of turbidity in three out of the five stations were for instance beyond the maximum value of 25 NTU recommended for aquatic life (Moore, 1989; Michaud, 1991).

The $\mathrm{pH}$ values of the lake showed positive correlation with zooplankton occurrence. This was probably because the recorded $\mathrm{pH}$ values (6.60-7.83) were within the recommended range (6.0-9.0) for aquatic life (Chapman and Kimstach, 2006). pH values outside this range could negatively affect the distribution of zooplankton in the lake.

Total alkalinity, conductivity, TDS, $\mathrm{Ca}^{2+}, \mathrm{Na}^{+}, \mathrm{K}^{+}$and $\mathrm{SO}_{4}{ }^{2-}$ all had direct relationships with either abundance or occurrence of zooplankton in the lake, while $\mathrm{Cl}^{-}$ showed inverse relationship. This implies that dissolved salts and minerals are necessary components of good quality water as they help maintain the health and vitality of aquatic organisms that rely on this ecosystem service (Stark et al., 2000). The direct relationships may also be supported by the fact that the mean values of alkalinity exceeded the minimum value of $24 \mathrm{mgCaCO}_{3} \mathrm{~L}^{-1}$ recommended for aquatic life, while $\mathrm{Ca}^{2+}, \mathrm{Na}^{+}$and $\mathrm{K}^{+}$did not exceed their recommended limits for aquatic life $\left(<15.0 \mathrm{mgL}^{-}\right.$ 1 , $<50.0 \mathrm{mgL}^{-1}$ and $<10.0 \mathrm{mgL}^{-1}$ respectively) (Chapman and Kimstach, 2006). Changes in the ionic composition of water can exclude some species while promoting the population growth of others (WeberScannell and Duffy, 2007). This was the probable reason for the direct relationships between zooplankton abundance and various ions $\left(\mathrm{Ca}^{2+}, \mathrm{Na}^{+}\right.$, $\mathrm{K}^{+}$and $\mathrm{HCO}_{3}{ }^{-}$) in the lake in spite of the inverse relationship between species occurrence and $\mathrm{Cl}^{-}$. Chloride ion is one of the major ions that determine the salinity of water body. Its inverse relationship with species occurrence is further supported by the fact that the diversity of aquatic species declines as osmotic tolerances are exceeded with increasing salinity (Derry et al., 2003). Increases in salinity also cause shifts in biotic communities, limit biodiversity, exclude less-tolerant species and cause acute effects at specific life stages (Weber-Scannell and Duffy, 2007). Magnesium, sodium, potassium and calcium concentrations tend to be influenced by metabolic activities of aquatic organisms and can exhibit marked seasonal and spatial dynamics as a result of biological activity. Chloride concentrations can also be influenced by biological activity, while $\mathrm{SO}_{4}{ }^{2-}$ and $\mathrm{HCO}_{3}{ }^{-}$ can be driven by production and respiration cycles of the aquatic biota (Wetzel, 2001). These ions have also been reported as being responsible for salinity in a body of water. The level of salinity in aquatic systems is important to aquatic plants and animals as species can survive only within certain salinity ranges (Friedl et al., 2004). The significant positive correlations recorded between zooplankton species occurrence/abundance with $\mathrm{Ca}^{2+}, \mathrm{Na}^{+}, \mathrm{K}^{+}, \mathrm{HCO}_{3}{ }^{-}, \mathrm{Cl}^{-}$ and $\mathrm{SO}_{4}{ }^{2-}$ in this study are further justified by the fact that the ions were within their preferred ranges for freshwater life.

Zooplankton communities respond to a wide variety of disturbances including nutrient loading (Dodson, 1992), and this was evident in the inverse relationships of $\mathrm{NO}_{3}^{-}$and $\mathrm{PO}_{4}{ }^{3-}$ with species occurrence. Nutrient compounds in the lake showed the same pattern as the hydro-physical parameters in their relationship with species occurrence. This implies that the concentrations of nutrient compounds were largely determined by the hydro-physical parameters which could in turn have been determined by allochthonous run-off and re-suspended autochthonous sediments in the rainy season. Nutrient compounds are expected to stimulate phytoplankton growth and by extension zooplankton growth, but their positive impacts could have been far outweighed by the high concentrations of hydro-physical parameters which are capable of limiting the euphotic zone, hence the inverse relationships between nutrient compounds and zooplankton species occurrence.

\section{CONCLUSION AND RECOMMENDATION}

This study has revealed that zooplankton fauna of Tiga Lake is limited by hydro-physical (turbidity, total solids and total suspended solids) and nutrient $\left(\mathrm{NO}_{3}{ }^{-}\right.$ and $\mathrm{PO}_{4}{ }^{3-}$ ) parameters, but enhanced by the general chemical characteristics (total dissolved solids, total alkalinity and conductivity) and major ions $\left(\mathrm{Ca}^{2+}, \mathrm{Na}^{+}\right.$, $\mathrm{K}^{+}$and $\left.\mathrm{HCO}_{3}^{-}\right)$. The ecological relationships found between zooplankton fauna and physico-chemical water condition of Tiga Lake indicated that the water body is suitable for aquatic life. Its productivity however seems to be threatened by high concentration of suspended solids, especially in the riverine section.

This study has also revealed that Tiga Lake has not been largely impacted by human activities and is under the close watch of the River Basin Development Authority. 
It is however important to closely monitor the basin from its inflows in order to slow down the aging process of the entire lake. This lake as well as other inland water bodies in Nigeria should also be accorded the same attention as other nature protected areas like national parks, in order to conserve our freshwater biological resources.

\section{REFERENCES}

Akinbuwa, O. (1999): The rotifera fauna and physicochemical condition of Erinle Lake and its major inflows at Ede, Osun State, Nigeria. Ph.D. Thesis. Obafemi Awolowo University, Ile-Ife, 327pp.

APHA, AWWA and WEF (1995): Standard methods for the examination of water and wastewater. $19^{\text {th }}$ ed. Washington.

Atoma, O. C. (2004): Spatial and temporal characteristics of phytoplankton and nutrient dynamics of the Imo River estuary, South Eastern Nigeria. Ph.D. Thesis, Department of Botany, University of Benin, Benin City, 220pp.

Boyd, C. E. (1979): Water quality management in pond fish culture. Auburn Inter. Centre for Aquaculture. For Aquaculture A.E. Station.

Carr, G. M. and Neary, J. P. (2006): Water quality for ecosystem and human health. United Nations Environment programme Global Environment Monitoring System Programme. 132pp.

(GEMS)/Water

Chapman, D. and Kimstach, V. (2006): Selection of water quality variables. In: Chapman, D. (ed.). Water quality assessments. Chapman and Hall, London, pp 65-122.

Derry, A. M., Prepas, E. E. and Herbert, P. D. N. (2003): A composition of zooplankton communities in saline lakewater with variable anion composition, Hydrobiologia, 505:199215.

Dodson, S. (1992): Predicting crustacean zooplankton species richness. Limnol. and Oceanography, 37: $312-324$.

Egborge, A. B. M. (1994): Water Pollution in Nigeria. Vol. I. Biodiversity and chemistry of Warri River. Ben Miller Books Nig. Ltd. 331pp.

Egborge, A. B. M. and Chigbu, P. (1988): The Rotifers of Ikpoba River, Bendel State. The Nigerian Field, 53: 117-132.

Fernando, C. H. (2002): A Guide to Tropical Freshwater Zooplankton; Identification, Ecology and Impact on Fisheries. Backhuys Publishers, Leiden. $291 \mathrm{pp}$.

Friedl, G., Teoderu, C. and Wehrli, B. (2004): Is the Iron Gate I Reservoir on the Danube River a sink for dissolved silica?, Biogeochemistry 68: 21-32.

Goltermann, R. I., Clymo R. S. and Ohnstad, M. A. M. (1978): Methods for Physical and chemical analysis of freshwater. IBP Handbook No 8. Blackwell Scientific Publication, Oxford. 214pp.

\section{ACKNOWLEDGEMENT}

I am greatly indebted to the Management and Staff of Hadejia Jama'are River Basin Development Authority for their kind approval to work on Tiga Lake, and the Department of Biological Sciences, Bayero University, Kano for their collaboration. The tremendous support of Dr. Y. K. Mustapha and Dr. I. I. Indabawa made this study feasible.

Haskoning Engineering Consultants Nigeria and Haskoning Nijmegen (1978): Tiga dam evaluation; operation and maintenance manual. Hadejia Jama'are River Basin Development Authority, $12 \mathrm{pp}$.

Marcarelli, A. M., Wurtsbaugh, W. A., and Griset, O. (2006): Salinity Controls Phytoplankton Response to Nutrient Enrichment in the Great Salt Lake, Utah, USA. Canadian Journal of Fisheries and Aquatic Sciences, 63: 22362248.

Michaud, J. P. (1991): A citizen's guide to understanding and monitoring lakes and streams. Publ. \#94-149. Washington State Dept of Ecology, Publications office, Olympia, WA, USA (360) 407-7472.

Mohan, M. and Kumar, S. (1998): Review of acid rain potential in India: Future threats and remedial measures. Current Science, 75: 579-593.

Moore, M. L. (1989): NALMS management guide for lakes and reservoirs. North American Lake Management Society (http: www.nalms.org).

Olele, N. F. and Ekelemu, J. K. (2008): Physicochemical and periphyton/phytoplankton study of Onah Lake, Asaba, Nigeria. African Journal of General Agriculture 4(3): 183-193.

Pilkaityte, R. and Razinkivas, A. (2006): Factors Controlling Phytoplankton Blooms in a Temperate Estuary: Nutrient Limitation and Physical Forcing. Hydrobiologia, 555: 41-48.

Stark, R.J., Hanson, P.E., Goldstein, R. M., Fallon, J. D., Fong, A. L., Lee, K. E., Kroening, S. E. and Andrews, W. J. (2000): Water quality in the Upper Mississipi River Basin,

Minnesota, Wisconsin, South Dakota, Iowa, and North Dakota, 1995-98. United States Geological Survey, Circular 1211. http://pubs.usgs.gov/circ/circ1211/pdf/circula r1211.pdf Last accessed July 4, 2006.

Weber-Scannell, P. K. and Duffy, L. K. (2007): Effects of total dissolved solids on aquatic organisms; a review of literature and recommendation for salmonid species, American Journal of Environmental Sciences, 3(1): 1-6.

Wetzel, R. G. (2001). Limnology. Third edition. Academic Press, U.S.A. 